\title{
The Liberalized Law of Standing
}

\author{
Kenneth Culp Davis†
}

Four Supreme Court cases, two in 1968 and two in 1970, have drastically liberalized the federal law of standing, giving it a new basic orientation. ${ }^{1}$ Yet satisfactory new criteria have not emerged, and the law of the subject is currently in turmoil. The Supreme Court has attempted to lay down guidelines, but its attempt has been largely unsuccessful.

The purpose of this essay is not only to summarize the new law but especially to analyze the criteria the Court has tried to formulate, and to advocate a simpler approach that may be more satisfactory. The law of standing, which the Supreme Court has called a "complicated specialty of federal jurisdiction," ${ }^{2}$ has long been too complex; and the recent developments have increased the complexity instead of reducing it. One good way to achieve simplicity is marked out by Justices Brennan and White in a 1970 opinion in which they assert that "injury in fact" should be the sole test for standing. ${ }^{3}$ Although two Justices cannot by themselves make law, they speak in this instance with special authority because the majority seems likely to retreat from what it has tried to create.

\section{The Four Key CASES}

The new law in perspective. Because the four Supreme Court decisions reject the old approach and move toward a new approach to the law of standing, they may be more important in answering current questions about standing than all previous decisions. Despite the present temporary confusion, the direction of movement is entirely clear: Many plaintiffs who did not have standing under pre-1968 law now have standing. Probably some plaintiffs who suffer "injury in fact" from illegal governmental action, still lack standing, but that is far from clear. Possibly the four cases have moved the law three-quarters

- + John P. Wilson Professor of Law, The University of Chicago.

1 Hardin v. Kentucky Util. Co., 390 U.S. 1 (1968); Flast v. Cohen, 392 U.S. 83 (1968); Ass'n of Data Processing Serv. Organizations v. Camp, 90 S. Ct. 827 (1970); Barlow v. Collins, 90 S. Ct. 832 (1970).

2 United States ex rel. Chapman v. FPC, 345 U.S. 153, 156 (1953).

3 $90 \mathrm{~S}$. Ct. at 841 (concurring and dissenting opinion for Data Processing and Barlow). 
of the distance from the pre-1968 law to the position that "injury in fact" is the sole test. Justices Brennan and White have firmly reached that destination. The other six stop short of it, but their stopping point seems untenable and will apparently have to be moved in one direction or the other. That the lower courts have increasingly adopted "injury in fact" as the test is also significant, ${ }^{4}$ although some courts are either unaware of the new law or are resisting it. ${ }^{5}$

The Hardin case. ${ }^{\circ}$ The significance of Hardin $v$. Kentucky Utilities Co. may lie more in what the Supreme Court read into it later than in what the opinion said. A private utility sought to enjoin the Tennessee Valley Authority from supplying power to towns served primarily by the plaintiff, in contravention of a 1959 statute forbidding TVA to sell power outside "the area for which [it was] the primary source of power" in 1957. The Court distinguished cases holding that economic injury from competition is not a basis for standing by saying that those cases involved injury "from lawful competition" and by saying that "when the particular statutory provision invoked does reflect a legislative purpose to protect a competitive interest, the injured competitor has standing to require compliance with that provision."8 The Court went on to find that the 1959 statute was designed "to protect private utilities from TVA competition" and that accordingly the plaintiff had standing. The Court was unanimous on the question of standing, and the opinion made that question appear to be easy.

The central proposition of Hardin that parties whose interests are protected by statute have standing to ask the court to carry out the congressional will is almost too obvious to state. Of course such parties have standing. And that is all that the Court held. The significance of the case does not lie in its holding. It lies in (1) the negative proposition that has later been read into the opinion that parties do not have standing unless they have interests protected by a statute-a proposition the Court did not state-and (2) the language partially discrediting a leading case ${ }^{9}$ that had become the foundation for much law that a competitive interest alone cannot be enough for standing. The Court said in a footnote: "The Court in [Kansas City Power \& Light Co. v.] McKay ruled that an explicit statutory provision was necessary to

4 Outstanding are Air Reduction Co. v. Hickel, 420 F.2d 592 (D.C. Cir. 1969), and Scanwell Laboratories v. Thomas, - F.2d - (D.C. Cir. 1970).

5 E.g., Rasmussen v. United States, 421 F.2d 776 (8th Cir. 1970).

6 Hardin v. Kentucky Util. Co., 390 U.S. 1 (1968).

7390 U.S. at 3.

$8 \mathrm{Id}$. at 6.

9 Kansas City Power \& Light Co. v. McKay, 225 F.2d 924 (D.C. Cir.), cert. denied, 350 U.S. 884 (1955). 
confer standing because of the 'long established rule' that an injured competitor cannot sue to enforce statutory requirements not designed to protect competitors. In the case of statutes concerned with protecting competitive interests, the 'long established rule' is of course precisely the opposite."10 That was a big blow to the structure of case law the lower courts had built on the foundation of McKay, for judicial opinions had cited it about eighty times; without the McKay support, a large portion of that structure had to fall, and something else had to be erected in its place.

The Flast case. ${ }^{11}$ This second case in the series, holding that a federal taxpayer in some circumstances has standing to challenge the validity of a federal expenditure, has been fully discussed elsewhere by the present writer. ${ }^{12}$ The opinion greatly contributed to the liberalization of the law of standing, although the specific issue was a highly specialized one.

The Data Processing case. ${ }^{13}$ This case and the Barlow case were decided the same day, Mr. Justice Douglas writing both majority opinions. Mr. Justice Brennan wrote for both cases a single opinion concurring and dissenting, joined by Mr. Justice White. The Barlow opinion throws light on the meaning of the Data Processing opinion.

The question in Data Processing was whether sellers of data processing services had standing to challenge a ruling of the Comptroller of the Currency allowing national banks to provide such services. That both the district court and the court of appeals had denied standing tends to show what the law had become. The district court had said, quite accurately: "There is a long and well established line of judicial authority holding that plaintiffs whose only injury is loss due to competition lack standing to maintain legal action to redress their economic injury." 14 It cited nine cases, including three Supreme Court cases. The Eighth Circuit had said that "the courts uniformly have denied standing to competitors who otherwise possess no legal right to be free from competition,"15 and it had quoted from Tennessee Electric Power Co. v. TVA that one is without standing unless "the right invaded is a legal right,-one of property, one arising out of contract, one protected against tortious invasion, or one founded on a statute which confers a privilege."16 The Eighth Circuit then had generalized: "Unless a rele-

10390 U.S. at 7 n.7.

11 Flast v. Cohen, 392 U.S. 83 (1968).

12 Standing: Taxpayers and Others, 35 U. CHr. L. REv. 601 (1968).

13 Data Processing Serv. Organizations v. Camp, 90 S. Ct. 827 (1970).

14279 F. Supp. 675, 678 (D. Minn. 1968).

15406 F.2d at 839 .

16306 U.S. 118, 137-8 (1939). 
vant statute provides for a 'party in interest' to seek judicial review or unless a complainant possesses a recognized legal interest, he lacks standing to be a 'private attorney general' to represent the public interest." 17 The view of the lower courts was well supported, although the case law was not free from confusion. The Tennessee Electric remark had often been used to deny standing to competitors in circumstances like those of the Data Processing case, even though the present writer had branded the remark a "palpably false proposition."18

In reversing, the Supreme Court quoted the Tennessee Electric remark and specifically rejected it, saying only: "The 'legal interest' test goes to the merits. The question of standing is different. It concerns, apart from the 'case' or 'controversy' test, the question whether the interest sought to be protected by the complainant is arguably within the zone of interests to be protected or regulated by the statute or constitutional guarantee in question." 19 The Court emphasized in a footnote that "the existence or non-existence of a 'legal interest' is a matter quite distinct from the problem of standing." 20

A huge portion of the former foundation of the law of standing was thus knocked out. The old test of "a recognized legal interest" was specifically rejected. In its place were two new tests. The first, based on Article III, was "injury in fact, economic or otherwise." The Court found this test satisfied by the injury from new competition. The second test-and this is the essence of what the Court tried to create-was "whether the interest sought to be protected by the complainant is arguably within the zone of interests to be protected or regulated by the statute or constitutional guarantee in question."

The Court gave meaning to the second test by applying it in Data Processing and in Barlow. The application in the first opinion was reasonably satisfactory, but the application in Barlow involved an unfortunate inadvertence or misunderstanding, as we shall see. In Data Processing, section 4 of the statute provided: "No bank service corporation may engage in any activity other than the performance of bank services for banks." 21 Section 4 on its face does not say that Congress intended to protect nonbank data processors from bank competition.

17406 F.2d at 843.

18 R.C. Davis, Administrative Law Treatise 217 (1958). If the words are taken literally, no one could challenge a statute outlawing the Baptist Church, or prohibiting Republican speeches, or denying criminal defendants a jury trial, or authorizing unlawful searches, or compelling witnesses to testify against themselves. If the words are not taken literally, what do they mean?

$1990 \mathrm{~S}$. Ct. at 830 .

2090 S. Ct. at 829 n.1.

21 Bank Service Corporation Act of 1962, 12 U.S.C. $\$ 1864$ (1964). 
But the First Circuit had made a statement which the Supreme Court quoted in full, and which must here be quoted almost in full:

Section 4 had a broader purpose than regulating only the service corporations. It was also a response to the fears expressed by a few senators, that without such a prohibition, the bill would have enabled "banks to engage in a nonbanking activity," S.Rep. No. 2105 . . . and thus constitute "a serious exception to the accepted public policy which strictly limits banks to banking." . . . We think Congress has provided the sufficient statutory aid to standing even though the competition may not be the precise kind Congress legislated against. $^{22}$

After quoting that passage, the Supreme Court said, and it said no more on the question of standing: "We do not put the issue in those words, for they implicate the merits. We do think, however, that $\S 4$ arguably brings a competitor within the zone of interests protected by it." 23

The Barlow case. ${ }^{24}$ The Supreme Court held in Barlow that tenant farmers had standing to challenge a regulation which increased their freedom from governmental restraint-which released the tenant farmers from restrictions imposed by a prior regulation. The statute provided for payments to the farmers but permitted them to assign payments only "as security for cash or advances to finance making a crop."25 The prior regulation had defined "making a crop" to exclude assignments to secure rent for a farm. The challenged regulation defined "making a crop" to include such assignments. The challenged regulation thus permitted the tenant farmers to do something the prior regulation prohibited. They objected to the new regulation because it allegedly allowed landlords to compel them to obtain financing of all their farm needs from the landlords, who charged such high interest that their profits each year were consumed in debt payments.

The district court, applying traditional law, denied standing on the ground that no legally protected interest of the tenant farmers was invaded. ${ }^{26}$ A divided Fifth Circuit affirmed on that ground; it neatly expressed the traditional law, quoting an earlier opinion: "Thus, in the absence of an express or implied statutory grant of standing, mere economic harm to an appellant 'made possible by government action

22 Arnold Tours, Inc. v. Camp, 408 F.2d 1147, 1152-3 (1st Cir. 1969).

$2390 \mathrm{~S}$. Ct. at 831.

24 Barlow v. Collins, 90 St. Ct. 832 (1970).

25 Soil Conservation and Domestic Allotment Act, 16 U.S.C. § 590h(g) (1964).

26 Unreported. 
(even if allegedly illegal) does not give standing to sue to restrain such action." "27 The court came to grips with the specific question when it said of landlords' encroachment on tenants' economic bargaining power: "This is nothing more than an economic consequence permitted, but not required, by government action." 28 Judge Tuttle in dissent asserted that the statute conferred a "right" on the tenants to make assignments for making a crop "and restricting their right to assign for any other purpose."29

The district court, the majority of the courts of appeals, and the dissenter all addressed themselves to the issue presented-whether the particular interest the tenant farmers were asserting was sufficient for standing.

Surprisingly, the Supreme Court wrote an opinion which never reached that issue. Instead, the Supreme Court reversed on two grounds: "First, ... the tenant farmers ... have the personal stake and interest that impart the concrete adverseness required by Article III. Second, the tenant farmers are clearly within the zone of interests protected by the Act."30

The Court's second ground needs special attention. What was it that had to be within the zone of protected interests-(a) the tenant farmers, (b) their interests in general, or (c) the particular interest they were asserting? Obviously, the answer should be the particular interest. The Court went wrong in saying "the tenant farmers are clearly within the zone...." That formulation, however, was a mere verbal infelicity of no consequence. But the Court's exclusive focus on the "interests of the tenant farmers," along with its complete failure even to consider the particular interest the farmers were asserting, goes to the essence of the Court's analysis and holding. The Court wrote a paragraph to show that Congress meant to protect "the interests of tenant farmers," quoting statutory language that the Secretary "shall provide adequate safeguards to protect the interests of tenants" and "shall, as far as practicable, protect interests of tenants." 31 But those two quotations govern payments of money, not assignments. The opinion had only one sentence about assignments: "The legislative history of the 'making a crop' provision, even though sparse, similarly indicates a congressional intent to benefit the tenants," and the Court supported that sentence with a footnote about "congressional concern for the farmers' welfare." 32

27398 F.2d 398, 400 (5th Cir. 1968).

$28 \mathrm{Id}$. at 402.

20 Id. at 403.

$3090 \mathrm{~S}$. Ct. at 896.

31 Id.

32 Id. n.7. 
The outstanding fact about the Barlow opinion is that the Court did not mention and did not directly or indirectly consider the question whether the particular interest the tenant farmers were asserting should be a basis for standing, or whether that interest was within the zone of interests "to be protected" by the statute.

Even though the Court clearly indicated that standing does not depend upon the interest the plaintiff asserts but depends upon "congressional concern" for his "welfare," could the Court possibly have meant that? If it did, the pride of Farmer Smith in trying to keep up with the Joneses gives Smith standing to challenge an overpayment by the government to the Joneses. Not only that, but Congress somewhere has probably expressed its "concern" for the "welfare" of human beings, and therefore every human being satisfies the test. Interpreted as the Court interpreted it in Barlow, the test becomes nonsensical.

The conclusion seems compelled that the Court could not have meant that the farmers' interests in general are the basis for their standing, as distinguished from the particular interest the farmers were asserting. The failure of the Court to examine the particular interest must have been in the nature of an inadvertence. Despite the Court's analysis and action in Barlow, the Court probably did not intend to change its formulation in the Data Processing opinion that the test is "whether the interest sought to be protected by the complainant is arguably within the zone. ..."33

If the Court had not fallen into its inadvertence-if it had addressed itself to the question whether the particular interest asserted was arguably within the zone of interests to be protected-what would it have held? One can only speculate: Probably no congressional intent can be found that the interest of the farmers in continuing the restriction on their legal capacity to make assignments either was "to be protected" or was not "to be protected." Applying the Court's test as stated in Data Processing would probably have meant a denial of standing. If so, would not the Court probably have discerned the inadequacy of the test it was trying to create, and might it not then have backed away from that test?

In the remainder of this essay, we shall assume that the Court's failure to reach the question whether the farmers' particular interest was enough was only an inadvertence, and that the Court meant to establish two tests for standing- "injury in fact" and whether the particular interest asserted is "arguably within the zone of interests to be protected or regulated by the statute or constitutional guarantee in question." 


\section{The Live Issue-The Brennan-White Position}

In Data Processing and Barlow, the Supreme Court unanimously superseded a large batch of law that was built on such doctrine as that of the $M c K a y$ case ${ }^{34}$ that something in the nature of a "legal right" or "legal interest" was necessary for standing. That shift is a great accomplishment and it deserves strong emphasis, for federal law of standing now has a new and better orientation. But that much is no longer a live issue, for it has been fully resolved by a unanimous Court.

The live issue now is not whether the Court should have vastly broadened the class of those who have standing; the live issue is whether still further broadening is needed. Justices Brennan and White in a "concurring and dissenting opinion" asserted that it is. ${ }^{35}$ The Brennan opinion adopted the view that "injury in fact" should be the sole test and that an additional test was "wholly unnecessary and inappropriate" and "a useless and unnecessary exercise ... which may well deny justice in this complex field." 36 The main reliance of the Brennan opinion was on the Flast case: "In the light of Flast, standing exists when the plaintiff alleges, as the plaintiffs in each of these cases alleged, that the challenged action has caused him injury in fact, economic or otherwise."37

The question whether "injury in fact" should be the sole test for standing is an open question not merely because Justice Brennan and White assert that it should be, but also because the unsatisfactory opinion of the majority in Barlow cannot close that question, and, in addition, because no holding of the Supreme Court has yet resolved the question. Since it began its liberalization of the law of standing in 1968, the Supreme Court has not denied standing to any party.

More precisely, the live issue that is worth discussing is this: Assuming that the Court in due course will correct the inadvertence that mars the Barlow opinion, so that standing will not depend upon "the interests" of the plaintiff but upon the particular interest asserted, should standing be denied to one who shows "injury in fact" but who cannot show that the interest he is asserting is "arguably within the zone of interests to be protected or regulated by the statute or constitutional guarantee in question"?

The reasons for rejecting the requirement that the asserted interest be "arguably within the zone" are very powerful. As will now be argued, that requirement is (1) analytically faulty, (2) contrary to much

34 Kansas City Power \& Light Co. v. McKay, 225 F.2d 924 (D.C. Cir.), cert. denied, 350 U.S. 884 (1955).

$3590 \mathrm{~S}$. Ct. at 838.

$36 \mathrm{Id}$. at 840 .

37 Id. at 841 . 
case law the Court should not have intended to overrule, (3) cumbersome, inconvenient, and artificial, and (4) at variance with the dominant intent behind the Administrative Procedure Act.

\section{Criticism of the New LAW}

(1) The test is analytically faulty. The test requiring that the asserted interest of one who is injured in fact must be "arguably within the zone of interests to be protected or regulated by the statute or constitutional guarantee in question" has two parts- "to be protected" and "to be regulated," and the two parts call for separate discussion.

A requirement that the plaintiff's asserted interest be arguably within the zone of interests "to be protected" by the statute or constitutional guarantee is analytically faulty in that it ignores the need for continuing common-law protection of some interests. It would mean, for instance, that an equity court could no longer decide, on the basis of its conception of what equity requires, that particular nonstatutory and nonconstitutional interests should be entitled to judicial protection.

The freedom of judges to go on determining that new interests emerging from new conditions or new understanding must be preserved. The whole development of the common law through the centuries has involved the creation of new "common-law rights." Obviously, that process should not be terminated. And if judges' power to create new "rights" must be continued, their smaller power to do something less than that-to recognize that some new interests suffice for standingmust likewise be continued.

The second part of the test, concerning interests "to be ... regulated," is even more seriously faulty. A plaintiff should have standing if he is in fact regulated to his disadvantage; to have standing he should not be required to show that the interest he asserts is within the zone of interests "to be" regulated by the statute or constitutional guarantee.

For instance, if a statute authorizes the administrator to regulate from $\mathrm{A}$ to $\mathrm{M}$, and he regulates $\mathrm{X}$ without statutory authorization, $\mathrm{X}$ should obviously have standing to challenge, but he does not have under the Court's test, for he cannot show that he is "to be" regulated.

A recent case $^{38}$ will help show that the Court's test is faulty. The Helium Act required government agencies to "purchase all major requirements of helium" from the Secretary of the Interior., ${ }^{39}$ Pursuant to the statute, the Secretary issued regulations requiring contractors with government agencies to purchase their helium from the Secretary.

38 Air Reduction Co. v. Hickel, 420 F.2d 592 (D.C. Cir. 1969).

3950 U.S.C. § 167d(a) (1964). 
The regulations caused a private producer of helium to lose business, and it sued for a determination that the regulations were in excess of the Secretary's authority. The court answered the question of standing in a single sentence, which seems satisfactory in all respects: "The Secretary's regulations would interfere with appellees' existing beneficial business relations . . . and are subject to challenge by appellees on the ground that they are invalid. ..."40 The court then held the regulations in excess of the Secretary's authority. The holding that the producer had standing seems clearly in line with common sense and with justice. Yet the producer was neither "to be protected" nor "to be regulated" by the statute and would therefore be without standing under the Supreme Court's test.

(2) The test is contrary to much case law the Court could not have meant to overrule. The basic thrust of the Supreme Court's four recent decisions is to liberalize the law of standing. But the test the Court proposes would close the judicial doors to many parties to whom the doors have long been open. The Court could not have intended to overrule all such cases. Many examples could be given; only a few are here selected.

In the 1902 case of American School of Magnetic Healing v. McAnnulty, ${ }^{41}$ the Court accepted as true the School's allegation that it had engaged in no fraud but that the Postmaster General had issued a fraud order against it. The statute said nothing directly or indirectly about interests "to be protected;" it provided neither for procedural protections nor for judicial review. Of course, it did not provide that one not engaging in fraud was "to be regulated." The protection the Court gave the School came from the equity court, not from the statute; the Court spoke of "irreparable injury" and of the need for equitable relief. The School's standing was so clear that the Court did not discuss it. Yet under the Court's test, the interest the School was asserting was not within the zone of interests "to be protected" or "to be regulated" by the statute, and therefore the School would lack standing.

A major function of federal courts is to protect private parties from being "injured in fact" by unlawful action of government officers, despite the failure of Congress to say directly or indirectly in the statute or in the legislative history that the interest asserted by the private party is "to be protected" or "to be regulated." The gradually developed system of using courts to keep officers and agencies within their powers is mostly the result of judge-made law. "The responsibility of determining the limits of statutory grants of authority ... is a judicial function entrusted to the courts by Congress by the statutes establishing 
courts and marking their jurisdiction." 42 Equity steps in as justice requires, and when the remedy is beyond the statute the interests protected may be. ${ }^{43}$

When an order against a corporation affects the separate interest of stockholders, as when their equity will be diluted, they have standing by reason of their separate interest. The cases so holding do not rest upon any finding that the stockholders are "to be protected" or "to be regulated" by the statute. ${ }^{44}$

When the Postmaster General decided to experiment with sending first-class mail by air, the railroads asserted lack of statutory authority, and the court, impressed by the extent of the railroads' investments in mail carrying, upheld their standing, without anything in the nature of a finding that they were "to be protected" or "to be regulated" by the statute. ${ }^{45}$

Federal courts have held in a long line of cases that existing banks have standing to challenge approval by the Comptroller of the Currency of new banks or of new branches that will compete with existing banks. If Congress has ever expressed or implied its intent that existing banks are "to be protected" from new competition, that intent has not been brought out in the opinions. Only a few of the cases will be mentioned. An early case reasoned that if the competition was unlawful it was unfair competition, citing the Restatement of Torts. ${ }^{46}$ Very common is the simple reasoning that if the Comptroller acts illegally, the plaintiff who is hurt must have standing. ${ }^{47}$ One court held: "[A] competitor has an obvious interest sufficient to warrant his insistence that no branch bank be established through procedures or upon grounds not acceptable under the permissive statutes." 48 Another formulation:

42 Stark v. Wickard, 321 U.S. 288, 310 (1944).

43 For instance, after the Supreme Court had held in Shannahan v. United States, 303 U.S. 596 (1938), that an ICG determination was not reviewable under the Urgent Deficiencies Act governing review, the Court later allowed review in an injunction proceeding, saying that "the nature of the determination points to the propriety of judicial review." Shields v. Utah Idaho Cent. R.R., 305 U.S. 177, 183 (1938).

Another well-known case in which the entire review proceeding was outside the elaborate statutory scheme is Leedom v. Kyne, 358 U.S. 184 (1958).

44 American Power \& Light Co. v. SEC, 325 U.S. 385 (1945); Alleghany Corp. v. Breswick \& Co., 353 U.S. 151, 169 (1957).

45 Atchison, T. \& S.F.R.R. v. Summerfield, 229 F.2d 777 (D.C. Cir.), cert. denied, 351 U.S. 926 (1956).

46 North Arlington Nat'l Bank v. Kearney Fed. Sav. \& Loan Ass'n, 187 F.2d 564, 565 (3d Cir. 1951).

47 E.g., Marion Nat'l Bank v. Saxon, 261 F. Supp. 373, 377 (N.D. Ind. 1966).

48 First Nat'l Bank of Smithfield v. Saxon, 352 F.2d 267, 272 (4th Cir. 1965). 
"[T] he banks surely have the standing to object to illegal competition." 49

Cases basing standing upon competitive interests, irrespective of presence or absence of an indication of legislative intent that competitive interests are "to be protected," are very common. A recent example is Matson Navigation Co. v. FMC,, 50 holding that a carrier has standing to challenge the Commission's approval of a merger which would result in "greater competition." Instead of examining the policy of the Shipping Act, the court simply cited FCC cases, governed by a different statute.

Persons debarred from contracting with the government were held to have standing to challenge the debarment order, but the court did not mention any congressional intent to "protect" or to "regulate" the debarred persons. The reason the persons debarred had standing was simply that they were hurt by the order. Judge Burger said for the court: "The injury to appellants alleged in their complaint gives them standing to challenge the debarment processes by which such injury was imposed." "r1 If "injury" was enough for Judge Burger, perhaps it will be enough for Chief Justice Burger.

In writing an opinion that television viewers and listeners have standing in a renewal proceeding before the FCC, Judge Burger said nothing about interests "to be protected" or "to be regulated." Instead, the court reasoned, in part: "Since the concept of standing is a practical and functional one designed to insure that only those with a genuine and legitimate interest can participate in a proceeding, we can see no reason to exclude those with such an obvious and acute concern as the

49 Webster Groves Trust Co. v. Saxon, 370 F.2d 381, 388 (8th Cir. 1966).

On a similar problem under a special statute, the court found a legislative intent to protect the competitive interest. Saxon v. Georgia Ass'n of Independent Ins. Agents, Inc., 399 F.2d 1010 (5th Cir. 1968), collecting a large number of cases on standing of banks to protect their competitive interests.

50405 F.2d 796 (9th Gir. 1968).

51 Gonzalez v. Freeman, 334 F.2d 570, 575 (D.C. Cir. 1964).

The Burger opinions in the Gonzalez and Church of Christ cases seem excellent, and therefore the deficiencies in his 1969 opinion in National Ass'n of Securities Dealers v. SEC, 420 F.2d 83 (D.C. Cir.), seem surprising. He wrote seven intensive pages on standing, seemingly maximizing complexities, and concluded: "My position therefore is one of reservation amounting to virtual disbelief in any standing in Appellees." Then, emphasizing that the questions were "of large public interest" and that no one else would be likely to challenge, he said that "in the uncertain state of the law as to standing, there is something to be said on both sides of that question. I therefore resolve my doubts in favor of the Appellees. ...."

Are principles of equality consistent with the idea that one who raises important questions may have access to the processes of justice but that one who raises unimportant questions may be denied such access? 
listening audience." 52 The Supreme Court surely could not have intended to supersede the decision of the court of appeals that "we hold that some 'audience participation' must be allowed in license renewal proceedings." 53

In a more recent Burger opinion, the court held that the second highest bidder for a government contract may challenge the validity of the highest bid. The court approved an injunction against acceptance of the highest bid, without even referring to the question of standing. ${ }^{54}$

Of the numerous recent opinions on standing, one of the most penetrating and helpful is a 1970 opinion of Judge Tamm for a unanimous court in Scanwell Laboratories $v$. Thomas. ${ }^{55}$ The plaintiff, who submitted the second lowest bid for instrument landing systems at airports, was held to have standing to challenge the Federal Aviation Administration's acceptance of the lowest bid on the ground that it was "non-responsive" within the meaning of the applicable regulation. The court did not inquire whether the interest was "to be protected" or "to be regulated." The approach was quite different-and better. The court reasoned, in part: "If there is arbitrary or capricious action on the part of any contracting official, who is going to complain about it, if not the party denied a contract as a result of the alleged illegal activity? It seems to us that it will be a very healthy check on governmental action to allow such suits ...."56 A most important part of the court's opinion is its conclusion, discussed below, that Congress "clearly" intended in the Administrative Procedure Act to confer standing upon "a party who is in fact aggrieved."

(3) The test is cumbersome, inconvenient, and artificial. The question of who has standing is a highly practical one that calls for quick and clear answers. The proposed requirement that the asserted interest must be within the zone of interests "to be protected or regulated" by the statute or constitutional guarantee usually leads into legislative history that cannot be easily consulted and the legislative history usually raises imponderable questions that cannot be answered with confidence until some voice of authority has spoken.

When Congress in 1895 enacted a brief statute authorizing the Postmaster General to issue fraud orders against those using the mails to defraud, it was so unconcerned about those not using the mails to defraud that it said nothing about them in the statute, and it said

52 Office of Communication of United Church of Christ v. FCC, 359 F.2d 994, 1002 (D.C. Cir. 1966).

$63 \mathrm{Id}$. at 1005.

54 Superior Oil Co. v. Udall, 409 F.2d 1115 (D.C. Cir. 1969).

$55-$ F.2d - (D.C. Cir. 1970).

56 Id. at - 
nothing about either procedural safeguards or judicial review. Was one not using the mails to defraud "to be protected" by the statute? One can wonder about this question after studying the statute. One can search the legislative history and come up with nothing-and go on wondering. Is not the inquiry artificial and unnecessary at all events? Even if Congress failed to indicate any intent concerning protection of one who was not using the mails to defraud, should not the court remain free to decide that such protection is needed and should be given? And is not the question whether protection should be given usually both a more sensible question and an easier one to answer?

Why not say that the equity court remains free-as equity courts always have been free--to provide such protection as the court deems fitting, in absence of an affirmative showing that Congress intended that such protection should be denied?

Every case discussed in the preceding section upheld standing, in each instance without a showing that the plaintiff's interest was within the zone of interests "to be protected or regulated" by the statute or constitutional guarantee. Could that showing be made in any of the cases? What would be required in each instance would be searching of legislative history and then some guessing about imponderables. For instance, in Gonzalez v. Freeman, ${ }^{57}$ the court held that those who wanted to contract with the government had standing to challenge an order debarring them, but it cited no statute. What are the statutes that might be relevant? Does the legislative history of all such statutes have to be searched? How long would that require for a skilful worker? What if the search shows that no one in Congress happened to think of the possibility of a debarment order, and what if no meaningful expression of congressional "concern" for the "welfare" of contractors happens to be found-must an unjust debarment order then be allowed to stand?

In the helium case the private producer was held to have standing because the Secretary's illegal action harmed "beneficial business relations." 58 If the Supreme Court's test had been used, standing would depend on whether the producer's interest was within the zone of interests "to be protected" by the statute. But the Helium Act on its face says nothing about protecting private producers against loss of business caused by unauthorized action of the Secretary, and the standing question under the test depends on what happens to have been said about protecting producers. One who turns to the Senate report finds nothing about protecting producers from loss of business.

57334 F.2d 570 (D.C. Cir. 1964).

58 Air Reduction Co. v. Hickel, 420 F.2d 592, 594 (D.C. Gir. 1969). 
The closest approach to an answer is a statement that the primary purpose was to assure a sustained supply of helium "to meet essential Government needs." "6ince the purpose goes to "Government needs," not private needs, perhaps private producers are not "to be protected." Or will protecting private producers contribute to "a sustained supply"? These questions can be answered either way. After all the work of consulting the legislative history, one comes up with seemingly silly questions that are seemingly unanswerable. Even if some remark had been made by the Senate Committee which, in the Court's Barlow language, expressed "concern" for the "welfare" of helium producers, would that not be a fortuitous basis on which to decide the standing question?

The awkwardness of the Court's test can be brought out by applying the test to pre-1968 cases in which courts have denied standing-and the exercise could possibly be profitable by incidentally shedding light on the new law of standing. Courts have held in a series of cases that an electric utility lacks standing to challenge a Rural Electrification Administration loan to a cooperative even though the new competition is economically harmful to the utility ${ }^{60}$ Are the cases still law? The general basis for the holdings was that the utility had "no legal right" under the Tennessee Electric Power test, which is rejected by Data Processing and Barlow. The crucial question is whether the utility's interest is "to be protected" under the Rural Electrification Act. The Act on its face is silent. ${ }^{61}$ So one who wants an answer must run down the legislative history. During debate, Senator McNary remarked: "[U]nder the language used, it seems to me, where a plant is now in existence which is adequately supplying a certain area with electricity none of the money provided by the bill could be used for that purpose," and Senator Norris, manager of the bill, responded, "That is as I understand it." 62 Representative Rayburn, manager of the bill in the House, said: "[W]e are not, in this bill, intending to go out and compete with anybody. By this bill, we hope to bring electrification to people who do not now have it. This bill was not written on the theory that we were going to punish somebody or parallel their lines or enter into competition with them." 63 Representative Fletcher said: "[T]here

591960 U.S. Code Cong. \& AD. News 3595.

60 Kansas City Power \& Light Co. v. McKay, 225 F.2d 924 (D.C. Cir.), cert. denied, 350 U.S. 884 (1955); REA v. Central La. Elec. Co., 354 F.2d 859 (5th Cir.), cert. denied, 385 U.S. 815 (1966); REA v. Northern States Power Co., 373 F.2d 686 (8th Cir.), cert. denied, 387 U.S. 945 (1967); Alabama Power Co. v. Alabama Elec. Cooperative, 394 F.2d 672 (5th Cir.), cert. denied, 393 U.S. 1000 (1968).

617 U.S.C. \$ 901 (1964).

6280 CoNG. REc. 2751 (1996).

63 Id. at 5283 . 
is no intention that the Rural Electrification Administration will sponsor competition with private enterprise ... [T] his program does not contemplate nor permit competition with existing public utilities."64

Are these statements enough to show that the interests of the existing utilities are "arguably within the zone of interests to be protected ... by the statute..."? The answer could be yes if enough emphasis is put on the word "arguably."

But the Senate Report quoted the REA Administrator: "The policy of the utility companies has been to skim off the cream of the business. Such a policy has precluded the extension of service to nearly 90 percent of American farms ... we have insisted upon the inclusion of all territory which can be covered in a self-liquidating project." ${ }^{65}$ Does this "arguably" pull in the opposite direction?

On the basis of the Court's test and of this legislative history, can any lawyer, either for an agency or for a private party, answer with assurance the question whether the utility has standing? And even if the remarks of the legislators were more favorable to the utility-or less favorable to it-should standing or lack of it depend upon the fortuities of who said what, without having the question of standing in mind?

Aside from the awkwardness and inconvenience of applying the Court's test, is not the question of who should have access to a court's processes more likely to be answered satisfactorily if a court is free to decide on the basis of what it deems to be the needs of justice?

(4) The test is contrary to the congressional intent in the Administrative Procedure Act. Neither the Supreme Court nor any other court has ever written an opinion which makes a full-scale inquiry into the legislative history of the Administrative Procedure Act's provision on standing. Instead, what has happened in the main is that the leading $M c K a y$ case, ${ }^{66}$ now partially discredited, ${ }^{67}$ announced some conclusions on the basis of a superficial consideration, and other courts have largely followed that leadership.

The Supreme Court should examine the legislative history of the APA. When it does, it is likely to agree with the Court of Appeals for the District of Columbia, which in a carefully considered 1970 opinion concluded that "in spite of the fact that the Supreme Court has not yet chosen to hold that the Administrative Procedure Act applies to all situations in which a party who is in fact aggrieved seeks review,

64 Id. at 5307.

65 S. REP. No, 1581, 74th Cong., 2d Sess. (1986).

60 Kansas City Power \& Light Co. v. McKay, 225 F.2d 924 (D.C. Cir.), cert. denied, 350 U.S. 884 (1955).

67 See text at notes 9 \& 10 supra. 
regardless of a lack of legal right or specific statutory language, it is clearly the intent of that Act that this should be the case." 68

The Supreme Court in Data Processing and Barlow violated what the District of Columbia Circuit said was "clearly the intent" without even discussing the legislative history. Surely a full inquiry into the legislative history is in order.

The Act as codified provides: "A person suffering legal wrong because of agency action, or adversely affected or aggrieved by agency action within the meaning of a relevant statute, is entitled to judicial review thereof." 69

For standing, one need not suffer "legal wrong." That is the same as saying that one need not have a "legal right." One who lacks a legal right but who is "adversely affected or aggrieved by agency action within the meaning of a relevant statute" has standing. But do the words "within the meaning of a relevant statute" modify only the words "aggrieved by agency action" or do they also modify the words "adversely affected"? This question cannot be answered with confidence on the basis of examining the statutory words, for the phraseology is ambiguous. But the legislative history does answer the question.

Both the Senate Committee and the House Committee said: "This subsection confers a right of review upon any person adversely affected in fact by agency action or aggrieved within the meaning of any statute."70

The statement by the Committee differs in two respects from the statutory provision: (1) It adds the words "in fact" after "adversely affected." (2) It puts the words "by agency action" after "affected in fact" and thereby tends to show that the words "within the meaning of any statute" do not modify "adversely affected in fact." The two differences pull in the same direction; both pull toward the conclusion that the Committees intended to confer the right of review upon "any person adversely affected in fact by agency action."

The statement by the Committees seems to mean that "any person affected in fact by agency action" is entitled to review, and that "any person ... aggrieved within the meaning of any statute" is entitled to review.

One would have to strain the words of the Committees to interpret

68 Scanwell Laboratories v. Thomas, - F.2d - (D.C. Cir. 1970).

695 U.S.C. \& 702 (Supp. II, 1967). The uncodified version did not differ in substance: "Any person suffering legal wrong because of any agency action, or adversely affected or aggrieved by such action within the meaning of any relevant statute, shall be entitled to judicial review thereof." 5 U.S.C. § 1009(a) (1964).

70 S. Doc. No. 248, 79th Cong., 2d Sess. 212, 276 (1946). 
them to mean that "any person adversely affected in fact by agency action ... within the meaning of any statute" is entitled to review, and that "any person ... aggrieved within the meaning of any statute" is entitled to review. For two reasons, finding that meaning in the Committees' words would strain those words: The words "in fact" after "adversely affected" seem to be inconsistent with the idea that the words "within the meaning of any statute" modify "adversely affected." And putting the words "by agency action" after "adversely affected" instead of putting them after "adversely affected or aggrieved" pulls away from an interpretation that the words "within the meaning of any statute" modify "adversely affected."

If the Committees had intended the words "within the meaning of any statute" to modify not only "aggrieved" but also "adversely affected," they could easily have left out the words "in fact" and they could have transposed the sentence to read: "This subsection confers a right of review upon any person who, within the meaning of any statute, is adversely affected or aggrieved." But the Committees did not say that. Instead, they conferred the right of review upon "any person adversely affected in fact by agency action" and upon "any person ... aggrieved within the meaning of any statute." This is the only meaning of the Committees' statement that does not strain its words.

The Committees would have no occasion to say "adversely affected in fact . . . within the meaning of any statute" unless some statute other than the Administrative Procedure Act provides for review at the instance of one "adversely affected in fact." But no such statute has come to the attention of this writer, and the probability seems strong that the Committees knew of no such statute. One who is "adversely affected" is entitled to review under the Communications Act, ${ }^{71}$ as well as under other statutes. One who is "aggrieved" is entitled to review under the Securities Act, ${ }^{72}$ as well as under other statutes. But no statute has been found which says that a person "adversely affected in fact" is entitled to review. The Committees mentioned no such statute. Therefore, they probably did not mean that one "adversely affected in fact ... within the meaning of any statute" is entitled to review. If they did not mean that, they must have meant what their literal words seem to say-that "any person adversely affected in fact by agency action" is entitled to review, and that "any person ... . aggrieved within the meaning of any statute" is entitled to review.

Other relevant legislative history, summarized elsewhere, "clutters

7147 U.S.C. \& 402(b) (1964).

72 15 U.S.C. $\$ 77 i(a)(1964)$. 
up the question more than it detracts from the committee's statements." 73

The Court of Appeals for the District of Columbia in its 1970 opinion seems to have strong support in the legislative history for its conclusion that "it is clearly the intent" of Congress in the APA that "a party who is in fact aggrieved" has standing. ${ }^{74}$ A reasonable argument could be made that the word "clearly" is unjustified. But clear intent need not be found. Intent is enough.

\section{Some Fundamentals about Standing}

The natural system is that of the common law: If $A$ and $B$ are private parties and $A$ hurts $B, B$ has standing to get a determination of the legality of A's action. Why should not the law be the same, whether $A$ is the government, and agency, an officer, or a private party, and whether the injury is to B's person, his physical property, or his intangible interests? Is not the natural system the simple one that injury in fact is enough for standing?

The only problems about standing should be what interests deserve protection against injury, and what should be enough to constitute an injury. Whether interests deserve legal protection depends upon whether they are sufficiently significant and whether good policy calls for protecting them or for denying them protection. The common law usually provides remedies for slight injuries to small interests-the touching of the person, a single footstep on one's land, the slightest dent of a fender. But the common law for policy reasons refuses to protect the criminal's interest in less police alertness, the defrauder's interest in easy access to gullible victims, or even the ordinary business man's interest in avoiding effective competition.

By and large, the state courts follow the common law attitudes in governing judicial review of administrative action, so that the judicial doors are widely open to anyone who asserts a legitimate interest; one who is hurt in fact has standing unless a statute or a "public policy" requires otherwise. The resulting law of standing is both simple and satisfactory. So is the state law that goes further and even allows any "citizen" or "resident" to raise questions about proper behavior of public officials. Opening the doors so widely does not mean that the courts are overrun with cases that ought not to be decided. It does mean that litigation about the law of standing is rather slight. 
Why, then, have the federal courts turned the law of standing into a "complicated specialty of federal jurisdiction"7s that keeps on producing a large volume of wasteful litigation that in turn keeps on adding to the complexity? The federal courts followed the natural system during the nineteenth century and the early part of the twentieth. The 1911 case of Muskrat $v$. United States ${ }^{78}$ may have initiated an attitude that has deepened. Mr. Justice Frankfurter's basic thinking, expressed in 1924 in $A$ Note on Advisory Opinions, ${ }^{77}$ was quite influential, preparing the way for the 1939 extreme pronouncement in Tennessee Electric Power that nothing short of infringement of a "legal right" would suffice for standing. ${ }^{78}$ The retention of that attitude has probably been motivated by various ideas not appearing on the face of formal opinions, such as the notion that the law of standing can keep judges from assuming too much governmental power, that it can limit courts to appropriate subject matter, that it can help assure competent presentation of cases, and, above all, that it can protect against a flood of litigation that might so much overburden the courts as to produce a disastrous deterioration in the quality of all that courts do.

Perhaps the time is approaching when the Supreme Court will correct these many misconceptions. The law of standing is the wrong tool to accomplish judicial objectives unrelated to the task of deciding whether a particular interest asserted is deserving of judicial protection. The courts should avoid hypothetical or remote questions-through the law of ripeness, not through the law of standing. The courts should decline to enter political areas-through the law of political questions, not through the law of standing. The courts should limit themselves to issues "appropriate for judicial determination"- -through the law of case or controversy, but not through that part of the law of case or controversy pertaining to standing. The courts should avoid taking over functions of government that are committed to executives or administrators-through the law of scope of review, not through the law of standing. The courts should virtually stay away from some governmental activities, such as foreign affairs and military operations-through the law of unreviewability, not through the law of standing. The courts should insist upon competent presentation of cases-through refusals to respond to inadequate presentations, not through the law of standing.

75 United States ex rel. Chapman v. FPC, 345 U.S. 153, 156 (1953).

76219 U.S. 346 (1911).

7737 HARV. L. REv. 1002 (1924).

78 Tennessee Elec. Power Co. v. TVA, 306 U.S. 118, 137-8 (1939). 
In recent years the unfortunate idea has blossomed in judicial opinions that the law of standing can be used to assure the competent presentation of cases. The Court in Baker $v$. Carr spoke of "such a personal stake in the outcome of the controversy as to assure that concrete adverseness which sharpens the presentation of issues . ..."79 The Court furthered that idea in Flast, saying that if the required "nexus" exists between the plaintiff's status and his claim of standing, "we feel ... that the questions will be framed with the necessary specificity, that the issues will be contested with the necessary adverseness and that the litigation will be pursued with the necessary vigor to assure that the constitutional challenge will be made in a form traditionally thought to be capable of judicial resolution." 80 The same idea cropped up in the Data Processing and Barlow opinions. ${ }^{81}$ The idea deserves a quiet burial. Standing should not depend upon the probable manner in which a party will present a case; it should depend only upon the question whether the plaintiff should be entitled to judicial assistance in order that justice may be done. Two simple illustrations, one at each pole, should suffice to show this: (1) The best law firm in the country, no matter how skilful its presentation to the court may be, obviously lacks standing to get an adjudication of an abstract question of law when neither it nor its client has any interest at stake. (2) An illiterate pauper who refuses legal assistance obviously has standing to challenge a $\$ 10$ fine imposed on him, no matter how badly he may present his case. Some interests the Supreme Court has properly held sufficient for standing include a fraction of a vote, a $\$ 1.50$ poll tax, and a fine of five dollars and costs. The law of standing cannot assure that questions will be framed with "specificity," that cases will be contested with "adverseness," or that litigation will be pursued with "vigor."

A social science research project could probably answer the question whether the waste involved in voluminous litigation about the com. plexities of the law of standing is greater than the waste that would result even from an extreme system of allowing standing to anyone who wants to be a plaintiff. In absence of a scientific answer, the courts must make a judgment. The Court of Appeals for the District of Columbia has recently done so, and it has come up with the convincing statement that when state courts have relaxed the requirements for standing "the dockets ... have not increased appreciably as a result of new cases

79369 U.S. 186, 204 (1962).

80 Flast v. Cohen, 392 U.S. 83, 106 (1968).

$8190 \mathrm{~S}$. Ct. at 836; $90 \mathrm{~S}$. Ct. at 841 . 
in which standing would previously have been denied." 82 The Second Circuit had previously made a similar observation..$^{83}$ Furthermore, experience of the federal courts themselves shows that floods of litigation do not result when the judicial doors are opened to all. A 1953 case $^{84}$ held that a "consumer"-anyone who eats-has standing to challenge action of the Food and Drug Administration; if consumers have brought many cases, they must all be unreported. Many statutes, including the Food and Drug Act and the Communications Act, have long provided specifically for standing of "any person adversely affected" but litigation under those statutes seems to be no more voluminous than litigation under other statutes. Half or more of the specific statutes are as broad-_"any person aggrieved," "any person disclosing a substantial interest," "any party in interest," but the litigation is in trickles, not floods.

Even without a social science research project, the courts should easily arrive at the conclusion that opening the doors to anyone "injured in fact" will not appreciably increase the number of parties who seek to litigate. It will cause an enormous drop in the huge volume of litigation in the federal courts about the complexities of the law of standing.

\section{Summary and Conclustons}

The Supreme Court in two 1968 opinions and in two 1970 opinions has drastically liberalized the law of standing, moving at least threequarters of the distance from the pre-1968 law to the position that "injury in fact" should be the sole test. In rejecting the old test, focused largely on "legal interest," the Court has been unanimous. The accomplishment is of great consequence; many plaintiffs now have standing who would have been denied standing before 1968 .

The live issue now is whether the Court should travel the remaining one-quarter of the distance to the sole test of "injury in fact." Justices Brennan and White have written a strong opinion saying it should. Six Justices have held back, attempting in the Data Processing opinion to create a second test that must be satisfied for standing- "whether the interest sought to be protected by the complainant is arguably within the zone of interests to be protected or regulated by the statute or con-

82 Scanwell Laboratories v. Thomas, - F.2d - (D.C. Cir. 1970).

83 "We see no justification for the Commission's fear that our determination [granting standing] will encourage 'literally thousands' to intervene and seek review in future proceedings. We rejected a similar contention in Associated Industries . . . noting that 'no such horrendous possibilities' exist." Scenic Hudson Preservation Conference v. FPC, 354 F.2d 608, 617 (2d Cir. 1965), cert. denied, 384 U.S. 941 (1966).

84 Reade v. Ewing, 205 F.2d 630 (2d Cir. 1953). 
stitutional guarantee in question." The Court stumbled in applying that second test in Barlow, for it decided whether the interests of the farmers in general were arguably within the zone, not whether "the interest sought to be protected" was. That failure went to the essence of the Court's holding, but it probably could not have been intended by the Court. The live issue is whether the second test as stated in Data Processing-not as applied in Barlow-should be added to the test of "injury in fact."

The reasons for rejecting the second test are powerful ones. The "to be protected" part of the test is analytically faulty in that an equity court would be deprived of its accustomed power to decide, on the basis of its conception of what equity requires, whether or not to provide judicial protection to nonstatutory and nonconstitutional interests. The "to be regulated" part is even more seriously faulty in that a person who is not "to be" regulated under the statute would lack standing to challenge an agency's unlawful regulation of him. The test would deny standing to many persons who have had standing under pre-1968 law, and the Court could not intend that, because its basic purpose is to liberalize the law of standing, not to restrict it. The test is needlessly cumbersome and inconvenient to judges and to practitioners, requiring search of legislative history and guesses about imponderables. The test adds to the complexity of the law of standing, and it adds to the uncertainty of what the law is on many particular problems. The test is contrary to the intent behind the Administrative Procedure Act; if the Supreme Court will for the first time make a careful examination of the APA's legislative history, it is likely to agree with a 1970 opinion of the Court of Appeals for the District of Columbia that "it is clearly the intent of that Act" that "a party who is in fact aggrieved" should have standing, although the Supreme Court might omit the word "clearly."

The main test should be "injury in fact," as Justices Brennan and White assert, but the Court's second test can be altered to make it a useful tool, mainly by shifting the burden to the other side: $A$ person whose legitimate interest is injured in fact should have standing unless congressional intent is discernible that the interest he asserts is not to be protected. This will mean judicial enforcement of whatever legislative intent is discernible, and also that in the many cases in which the statute and the legislative history show no intent either to protect the particular interest or not to protect it, injury in fact will be the sole test. Of course, no court will protect an interest that runs counter to public policy, such as the interest of a criminal in avoiding detection.

The presumption of reviewability should be broadened so that it will 
apply not only to subject matter but also to parties. The Supreme Court's remark in Abbott Laboratories, made in a context of reviewability, should be extended to apply to problems of standing: "[J]udicial review of a final agency action by an aggrieved person will not be cut off unless there is a persuasive reason to believe that such was the purpose of Congress." 85

The concept of "injury in fact" need not be pushed to its outer limits. The guide in marking out its limits should be whatever legislative intent is discernible, and in absence of such intent the guide should be a judicial judgment as to whether the interest asserted is in the circumstances deserving of judicial protection. A holding that a person is not "injured in fact" when the government confers a benefit on his competitor would be reasonable. The concept of "injury in fact" need not be rigid either as to what it includes or what it excludes. It can be kept both flexible and simple.

The nucleus of the law to guide applications of the test should be not only the Brennan-White opinion but also the opinions of Judge Burger (now Chief Justice) in Gonzalez ${ }^{86}$ and Church of Christ, ${ }^{87}$ the opinion of Judge Leventhal in the helium case, ${ }^{88}$ and the opinion of Judge Tamm in Scanwell Laboratories. ${ }^{89}$

Complexities about standing are barriers to justice; in removing the barriers the emphasis should be on the needs of justice. One whose legitimate interest is in fact injured by illegal action of an agency or officer should have standing because justice requires that such a party should have a chance to show that the action that hurts his interest is illegal.

The law of standing can be simple. Judge Leventhal's one-sentence opinion that a helium producer had standing to challenge regulations that caused a loss of customers seems entirely satisfactory: "The Secretary's regulations would interfere with appellees' existing beneficial business relations . . . and are subject to challenge by appellees ....."so

Such simplicity, with "injury in fact" as the main focus, has much to commend it.

\footnotetext{
85 Abbott Laboratories v. Gardner, 387 U.S. 136, 140 (1967).

86 Gonzalez v. Freeman, 334 F.2d 570 (D.C. Cir. 1964).

87 Office of Communication of the United Church of Christ v. FCC, 359 F.2d 994 (D.C. Cir. 1966).

88 Air Reduction Co. v. Hickel, 420 F.2d 592 (D.C. Cir. 1969).

89. Scanwell Laboratories v. Thomas, - F.2d - (D.C. Cir. 1970).

80 Air Reduction Co. v. Hickel, 420 F.2d 592, 594 (D.C. Cir. 1969).
} 